\title{
PENGARUH ASESMEN FORMATIF BENTUK PROYEK TERHADAP KEYAKINAN DIRI (SELF EFFICACY) DAN PRESTASI BELAJAR MATEMATIKA SISWA KELAS X-MIA SMA NEGERI 1 MARGA
}

\author{
I. M. W. P. Suarditha, I. M. Candiasa, I. G. N. Y. Hartawan \\ Jurusan Pendidikan Matematika, Universitas Pendidikan Ganesha \\ Singaraja, Indonesia \\ e-mail: wiraputra0211@yahoo.com, candiasaimade@yahoo.com.id, hartawan.math@gmail.com
}

\begin{abstract}
Abstrak
Penelitian ini merupakan penelitian eksperimen semu dengan rancangan post-test only control group yang bertujuan untuk mengetahui pengaruh asesmen formatif bentuk proyek terhadap keyakinan diri dan prestasi belajar matematika. Populasi penelitian ini adalah siswa kelas X-MIA SMA Negeri 1 Marga. Sampel ditentukan dengan teknik cluster random sampling setelah dilakukan uji kesetaraan populasi menggunakan ANAVA satu jalur. Data keyakinan diri siswa dikumpulkan dengan menggunakan angket, sedangkan data prestasi belajar matematika siswa dikumpulkan dengan tes prestasi belajar matematika bentuk uraian. Data yang diperoleh dianalisis menggunakan uji MANOVA. Hasil penelitian menunjukkan bahwa: pertama, terdapat perbedaan keyakinan diri dan prestasi belajar matematika antara siswa yang mengikuti pembelajaran dengan asesmen formatif bentuk proyek dan siswa yang mengikuti pembelajaran dengan asesmen konvensional $\left(F=5,599^{\mathrm{a}}\right.$ dan sig. $\left.=0,007 ; \rho<0,05\right)$; kedua, terdapat perbedaan keyakinan diri antara siswa yang mengikuti pembelajaran dengan asesmen formatif bentuk proyek dan siswa yang mengikuti pembelajaran dengan asesmen konvensional $(F=4,666$ dan sig. $=0,036 ; \rho<0,05)$; ketiga, terdapat perbedaan prestasi belajar matematika antara siswa yang mengikuti pembelajaran dengan asesmen formatif bentuk proyek dan siswa yang mengikuti pembelajaran dengan asesmen konvensional $(F=8,767$ dan sig. $=0,005 ; \rho<0,05)$. Dengan demikian asesmen formatif bentuk proyek berpengaruh positif terhadap keyakinan diri dan prestasi belajar matematika siswa.
\end{abstract}

Kata kunci: Asesmen formatif bentuk proyek, keyakinan diri, prestasi belajar matematika siswa.

\begin{abstract}
This study was a quasi experimental research with post-test only control group that aims to determine the influence of formative assessment in the project form towards self efficacy and achievement in learning mathematics. The population of this study were the tenth grade MIA students of SMA Negeri 1 Marga. The sample of this study was chosen by using cluster random sampling technique after implemented the equality of population was done by using ANOVA. The data of students self efficacy were collected by using questionnaire meanwhile, the data of students mathematic achievement were collected by using students mathematic learning achievement test. Then it was analysed by using MANOVA. The results showed that: first, there are differences of self efficacy and students mathematic achievement between those were taught by using formative assessment in the project form and those who were taught by using conventional assessment $\left(F=5,599^{\mathrm{a}}\right.$ and sig. $\left.=0,007 ; \rho<0,05\right)$; second, there are differences of self efficacy between those was taught by using formative assessment in the project form and those who were taught by using conventional assessment $(F=4,666$ and sig. $=0,036 ; \rho<0,05)$; third, there are differences of students mathematic achievement between those were taught by using formative assessment in the project form and those were taught by using conventional assessment $(F=8,767$ and sig. $=0,005 ; \rho<0,05)$. Thus the formative assessment in the project form a positive influence on self efficacy and students mathematic achievement.
\end{abstract}

Keywords: Formative assessment in the project form, self efficacy, students mathematic achievement. 


\section{PENDAHULUAN}

Pendidikan merupakan salah satu komponen penting dalam usaha meningkatkan kualitas sumber daya manusia (SDM). Melalui pendidikan, manusia sebagai subjek pembangunan dapat dididik, dibina dan dikembangkan potensi-potensinya. Kemajuan suatu bangsa tercermin pada keberlangsungan pendidikan bangsa itu. Dalam rangka mencerdaskan kehidupan bangsa, peningkatan mutu pendidikan suatu hal yang sangat penting bagi pembangunan berkelanjutan di segala aspek kehidupan manusia.

Salah satu bidang ilmu dalam dunia pendidikan yang sangat penting adalah matematika. Matematika merupakan dasar dalam mengembangkan bidang ilmu lain seperti teknologi. Begitu pentingnya peranan matematika sehingga mengharuskan setiap orang untuk mampu memahaminya. Menurut Permen Depdiknas No. 22 tahun 2006, pembelajaran matematika memiliki tujuan agar peserta didik memiliki kemampuan memahami konsep matematika, menggunakan penalaran pada pola dan sifat, memecahkan masalah, mengkomunikasikan gagasan dengan simbol, tabel, diagram atau media lain, dan memiliki sikap menghargai kegunaan matematika dalam kehidupan.

Mengingat pentingnya matematika sebagai ilmu dasar, maka pembelajaran matematika di berbagai jenjang pendidikan perlu mendapat perhatian yang serius. Dalam proses pembelajaran matematika, siswa tidak hanya bergantung pada apa yang diajarkan, tetapi juga bagaimana matematika diajarkan, atau bagaimana siswa tersebut belajar. Dengan demikian, guru sebagai pelaksana pembelajaran harus mampu menerapkan cara yang efektif dan efisien agar tujuan pembelajaran dapat dilaksanakan secara optimal, sehingga siswa lebih mempunyai keyakinan diri dalam belajar. Dengan adanya keyakinan diri dalam belajar, siswa akan dapat mencapai hasil yang diinginkan dalam pembelajaran.
Keyakinan diri (self efficacy) terdiri dari kata "self" yang dapat diartikan sebagai unsur struktur kepribadian, dan "efficacy" yang maknanya penilaian diri, apakah dapat melakukan tindakan yang baik atau yang buruk, tepat atau salah, bisa atau tidak bisa mengerjakan sesuatu. Keyakinan diri dikatakan sebagai sesuatu yang kompleks karena keyakinan diri akan menyebabkan terjadinya perubahan energi yang ada pada diri siswa. Menurut Bandura (1997), self efficacy adalah keyakinan seseorang terhadap kemampuannya untuk mengatur dan melaksanakan tindakan-tindakan untuk mencapai tujuan yang ditetapkan, dan berusaha untuk menilai tingkatan dan kekuatan di seluruh kegiatan. Keyakinan diri siswa didorong oleh adanya tujuan atau keinginan yang kuat dari dalam diri. Selain siswa harus memiliki keyakinan diri yang kuat, siswa juga harus mampu mencapai prestasi belajar yang maksimal.

Prestasi belajar merupakan penilaian pendidikan tentang kemajuan siswa dalam segala hal yang dipelajari di sekolah yang menyangkut pengetahuan atau keterampilan yang dinyatakan sesudah hasil penilaian (Djamarah, 1994). Selanjutnya menurut Nurjaman Hidayatullah (2010:324), "prestasi belajar menunjukkan tinggi rendahnya kualitas belajar siswa dalam pembelajarannya di sekolah serta dapat dijadikan ukuran atau pedoman dalam memperbaiki proses belajar mengajar". Secara umum, dapat disimpulkan bahwa prestasi belajar adalah hasil yang dicapai oleh siswa setelah siswa yang bersangkutan mengalami suatu proses belajar dalam jangka waktu tertentu.

Terdapat dua faktor yang mempengaruhi prestasi belajar siswa yaitu faktor intern dan faktor ekstern. Faktor intern merupakan faktor yang berasal dari dalam diri siswa, dapat berupa kecerdasan, keterampilan, bakat dan sikap. Faktor ekstern merupakan faktor yang berasal dari luar diri siswa, proses pembelajaran, sarana belajar, keadaan keluarga, lingkungan sekitar, dan sebagainya. Tinggi rendahnya kualitas 
faktor-faktor tersebut akan berpengaruh terhadap prestasi belajar siswa. Menurut Slameto (2003), faktor yang sering disebut sebagai penyebab belum maksimalnya prestasi belajar yang diperoleh siswa yaitu masih rendahnya kemampuan siswa dalam memahami pelajaran matematika, padahal guru di sekolah sudah melakukan usaha-usaha yang dapat meningkatkan prestasi belajar siswa.

Berdasarkan Programme for International Student Assessment (PISA) tahun 2015 yaitu studi internasional untuk melihat prestasi matematika dan sains siswa yang diadakan empat tahun sekali, peringkat anak-anak Indonesia bertengger di posisi 69 dari 76 negara. Hasil menurut data PISA tidak jauh berbeda dengan data yang diperoleh TIMSS (Trend in Mathematic and Science Study) tahun 2015 yang merupakan suatu bentuk evaluasi kemampuan dan pengetahuan yang dirancang untuk siswa. Indonesia menduduki peringkat ke 36 dari 49 negara untuk prestasi matematika. Dilihat dari hasil prestasi belajar siswa yang diperoleh oleh TIMSS dan PISA, dapat dikatakan bahwa prestasi belajar siswa Indonesia masih tergolong rendah.

Menyikapi hal tersebut, untuk mengatasi prestasi belajar siswa yang masih tergolong rendah selain model atau metode pembelajaran, masih ada hal lain yang perlu diperhatikan, salah satunya asesmen dalam pembelajaran. Asesmen merupakan bagian yang sangat penting dari kegiatan pembelajaran. Tujuan utama asesmen adalah meningkatkan kualitas belajar siswa, bukan sekedar penentuan skor. Asesmen juga dipandang sebagai kegiatan yang biasa dilakukan terpisah dalam pembelajaran dan umumnya dilakukan melalui tes pembelajaran. Tes seperti ini biasa dilakukan di akhir kegiatan pembelajaran untuk mengukur hasil belajar siswa. Asesmen diperlukan untuk memodelkan pembelajaran yang efektif, memonitor perkembangan pengetahuan siswa, dan menginformasikan tindakan yang diperlukan dalam pembelajaran. Keberhasilan proses pembelajaran tidak terlepas dari peran asesmen. Melalui asesmen guru akan terpadu menentukan metode atau pendekatan yang harus dilakukan agar pembelajaran efektif dan memiliki nilai tambah bagi siswa. Proses untuk mendapatkan pembelajaran efektif akan ditemukan melalui pengamatan dan refleksi dari kegiatan yang dilakukan. Semua informasi yang diperoleh dari berbagai sumber dan melalui berbagai teknik asesmen dijadikan acuan untuk menentukan jenis dan bentuk tindakan pembelajaran.

Bila penilaian atau asesmen yang dilakukan itu penilaian formatif, maka penilaian itu merupakan penilaian terusmenerus untuk memonitor keberhasilan siswa belajar selama pengajaran berjalan (Purnomo, 2013). Jadi fungsinya adalah sebagai umpan balik bagi guru dan siswa itu sendiri mengenai keberhasilan dan kegagalan siswa dalam belajar. Umpan balik bagi siswa adalah untuk melakukan perbaikan seperlunya mengenai kekeliruan dan penguatan bagi bagianbagian yang berhasil. Umpan balik bagi guru adalah untuk membuat perbaikan dan catatan pembuatan pengajaran remidial baik bagi kelompok maupun perorangan. Penelitian yang berkaitan dengan pemberian asesmen formatif bentuk proyek telah dilakukan oleh Artha Pradnyana (2016) dengan judul "Pengaruh Asesmen Formatif Bentuk Proyek Terhadap Kreativitas dan Pemahaman Konsep Matematika Siswa Kelas VIII di SMP Laboratorium UNDIKSHA Singaraja". Simpulan yang diperoleh adalah asesmen formatif bentuk proyek berpengaruh positif terhadap kreativitas dan pemahaman konsep matematika siswa.

Sampai saat ini sistem penilaian di SMA Negeri 1 Marga menggunakan teknik tes tulis. Penilaian dengan menggunakan teknik ini disebut asesmen konvensional. Teknik tes ini tidak selengkapnya dapat menggambarkan kemajuan belajar siswa secara menyeluruh, dengan demikian diperlukan adanya asesmen alternatif yang tidak hanya berupa tes tulis. Banyak tipe asesmen alternatif yang dapat digunakan, antara lain asesmen formatif bentuk proyek.

Marhaeni (2007) menyatakan bahwa asesmen formatif bentuk proyek adalah investigasi mendalam mengenai 
suatu topik nyata, dimana siswa mendapat kesempatan mengaplikasikan keterampilannya. Pelaksanaan proyek dapat dianalogikan dengan sebuah cerita, yaitu memiliki fase awal, pertengahan, dan akhir proyek. Hal ini berarti bahwa asesmen proyek dapat digunakan untuk mengetahui pemahaman, kemampuan mengaplikasikan, kemampuan penyelidikan dan kemampuan menginformasikan dari siswa pada mata pelajaran tertentu secara jelas, sehingga dalam asesmen formatif bentuk proyek guru tidak hanya melakukan evaluasi akhir yang hanya mengukur tingkat pemahaman melalui tes tertulis melainkan penilaian pemahaman siswa yang lebih ditekankan pada proses dan hasil yang diperoleh.

Dalam asesmen formatif bentuk proyek siswa diberikan permasalahan yang menuntut keyakinan diri siswa dalam memilih ide atau konsep dan mengidentifikasi berbagai cara atau strategi pemecahan masalah pada proyek, sehingga diperoleh prestasi belajar yang semakin membaik. Bercermin dari hal tersebut, penulis mengadakan penelitian untuk menyelidiki pengaruh asesmen formatif bentuk proyek terhadap keyakinan diri dan prestasi belajar matematika. Hal ini dikarenakan belum ditemukan penelitian yang secara tegas menyatakan tentang pengaruh asesmen formatif bentuk proyek terhadap keyakinan diri dan prestasi belajar matematika siswa. Dari uraian tersebut sangat beralasan bagi peneliti untuk meneliti asesmen yang sesuai dengan harapan serta tuntutan yang dipaparkan tersebut. Berdasarkan hal di atas, peneliti tertarik untuk melakukan penelitian yang berjudul "Pengaruh Asesmen Formatif Bentuk Proyek terhadap Keyakinan Diri (self efficacy) dan Prestasi Belajar Matematika Siswa Kelas X-MIA SMA Negeri 1 Marga".

\section{METODE PENELITIAN}

Penelitian ini berbentuk eksperimen semu dengan desain yang post-test only control group. Populasi dalam penelitian ini adalah seluruh siswa kelas X-MIA SMA Negeri 1 Marga tahun ajaran 2016/2017 yang berjumlah 76 orang. Pengambilan sampel dilakukan dengan teknik cluster random sampling dari populasi yang sudah diuji kesetaraannya dengan analisis varian satu arah. Data yang digunakan dalam pengujian kesetaraan populasi adalah nilai ulangan umum semester ganjil matematika siswa semester ganjil tahun ajaran 2016/2017. Diperoleh $F_{h i t}=0,40$ dan $F_{\text {tabel }}=3,13$. Karena $F_{\text {hit }}<F_{\text {tabel }}$, ini berarti ketiga kelas dalam populasi tersebut setara. Selanjutnya dilakukan pengundian dan diperoleh dua kelas sebagai sampel penelitian, yakni kelas XMIA 1 dan kelas X-MIA 2. Setelah melakukan pengundian kembali diperoleh kelas X-MIA 2 sebagai kelas eksperimen dan kelas X-MIA 1 sebagai kelas kontrol.

Variabel bebas dalam penelitian ini adalah asesmen formatif bentuk proyek sedangkan keyakinan diri dan prestasi belajar matematika sebagai variabel terikat. Data keyakinan diri dikumpulkan dengan angket berskala likert sedangkan prestasi belajar matematika dikumpulkan dengan tes uraian agar dapat menuntut siswa untuk dapat menyusun dan memadukan gagasan-gagasan tentang hal-hal yang telah dipelajari baik dalam menganalisis suatu masalah maupun dalam menyelesaikan perhitungan. Sebelum instrumen digunakan, terlebih dahulu dilakukan expert judgment oleh dua orang pakar guna mendapatkan kualitas angket yang baik, yang dilanjutkan dengan uji coba instrumen di lapangan, untuk mengetahui validitas dan reliabilitas instrumen tersebut. Penghitungan validitas dan reliabilitas instrumen angket keyakinan diri dan tes prestasi belajar matematika bentuk uraian menggunakan korelasi product moment dan Alpha Cronbach.

Korelasi product moment dari Carl

Pearson dengan rumus:

$$
r_{x y}=\frac{N \sum X Y-\left(\sum X\right)\left(\sum Y\right)}{\sqrt{\left(N \sum X^{2}-\left(\sum X\right)^{2}\right)\left(N \sum Y^{2}-\left(\sum Y\right)^{2}\right)}}
$$

(Candiasa, 2010a:116)

Alpha Cronbach dengan rumus: 
$r_{11}=\left(\frac{n}{n-1}\right)\left(1-\frac{\sum \sigma_{i}^{2}}{\sigma_{i}^{2}}\right)$

(Candiasa, 2010a:120).

Uji validitas isi angket keyakinan diri diperoleh 30 butir angket yang valid dengan $r=0,93$ yang tingkat realibilitas angket berada pada kategori sangat tinggi, sehingga dipilih 30 butir angket sebagai instrumen keyakinan diri. Uji validitas isi tes prestasi belajar matematika diperoleh 8 butir tes dinyatakan relevan dan setelah dilakukan uji coba diperoleh 8 butir tes dinyatakan valid dengan $r=0,68$ yang tingkat reliabilitas tes berada pada kategori tinggi. Sehingga 8 butir tes prestasi belajar matematika dipilih sebagai instrumen penelitian.

Data hasil penelitian dianalisis secara bertahap, tahapan-tahapan tersebut adalah analisis data, uji prasyarat dan uji hipotesis. Uji prasyarat yang dilakukan adalah uji normalitas sebaran data, uji homogenitas varians, dan uji korelasi antar variabel terikat.

1. Uji normalitas dilakukan untuk meyakinkan bahwa sampel berasal dari populasi yang berdistribusi normal, sehingga uji hipotesis dapat dilakukan. Uji normalitas data dianalisis menggunakan uji statistik Kolmonogrov-smirnov dengan bantuan SPSS 16.00 for windows pada taraf signifikansi 0,05 (Candiasa, 2010b)

2. Uji homogenitas varians untuk kedua kelompok dengan menggunakan uji Levene dengan bantuan SPSS 16.00 for windows pada taraf signifikansi 0,05 (Candiasa, 2010b).
3. Uji homogenitas varians/kovarian antar variabel terikat dengan menggunakan Uji Box's M (Candiasa, 2010).

4. Uji kolinieritas antar sesama variabel terikat dengan menggunakan korelasi product moment pada taraf signifikansi 0,05 dengan bantuan SPSS 16.00 for windows.

Setelah uji prasyarat terpenuhi, data selanjutnya akan dilakukan uji hipotesis penelitian dengan menggunakan uji MANOVA (Candiasa, 2010) dengan bantuan program SPSS 16.00 for windows. Untuk menguji hipotesis pertama digunakan uji $\mathrm{F}$ melalui MANOVA dengan kriteria pengujian taraf signifikansi $5 \%$. Keputusan diambil dengan analisis Pillae Trace, Wilk Lambda, Hotelling's Trace, Roy's Largest Root. Jika angka signifikansi $F$ hitung kurang dari 0,05 maka hipotesis nol ditolak, berarti terdapat perbedaan keyakinan diri dan prestasi belajar matematika antara siswa yang mengikuti pembelajaran dengan asesmen formatif bentuk proyek dan siswa yang mengikuti pembelajaran dengan asesmen konvensional. Pengujian hipotesis kedua dan ketiga dilakukan dengan uji MANOVA dengan taraf signifikansi 0,05 dimana tolak $H_{o}$ jika nilai signifikansi kurang dari 0,05 .

\section{HASIL DAN PEMBAHASAN}

Data mengenai skor keyakinan diri siswa yang diperoleh dari angket keyakinan diri yang diberikan kepada kedua kelompok sampel dapat dilihat pada tabel berikut.

Tabel 1. Hasil Analisis Data Keyakinan Diri

\begin{tabular}{ccc}
\hline Variabel & \multicolumn{2}{c}{ Kelompok } \\
\hline & Eksperimen & Kontrol \\
\hline $\mathrm{N}$ & 26 & 24 \\
\hline $\bar{X}$ & 97,58 & 91,83 \\
\hline $\mathrm{SD}$ & 10,33 & 8,25 \\
\hline Skor Maksimum & 150 & 150 \\
\hline
\end{tabular}

Keterangan

$\mathrm{N}$ : banyak siswa setiap kelompok
$\bar{X}$ : rata-rata skor keyakinan diri

SD : standar deviasi 
Sedangkan data mengenai skor prestasi belajar matematika siswa yang diperoleh dari post-test yang diberikan kepada kedua kelompok sampel dapat dilihat pada tabel berikut.

Tabel 2. Hasil Analisis Data Prestasi Belajar Matematika Siswa

\begin{tabular}{ccc} 
Variabel & \multicolumn{2}{c}{ Kelompok } \\
\hline & Eksperimen & Kontrol \\
\hline $\mathrm{N}$ & 26 & 24 \\
\hline $\bar{X}$ & 65,77 & 60,63 \\
\hline $\mathrm{SD}$ & 6,02 & 6,27 \\
\hline Skor Maksimum & 85 & 85 \\
\hline
\end{tabular}

Keterangan

$\mathrm{N}$ : banyak siswa setiap kelompok

$\bar{X}$ : rata-rata skor prestasi belajar matematika siswa

SD : standar deviasi

Berdasarkan tabel 1 dan 2 tersebut, maka untuk mengetahui apakah terdapat perbedaan keyakinan diri dan prestasi belajar matematika siswa kelompok eksperimen dan kontrol yang signifikan, maka perlu dilakukan uji MANOVA. Sebelum dilakukan uji hipotesis, terlebih dahulu dilakukan uji prasyarat terhadap sebaran data yang meliputi uji normalitas, uji homogenitas, uji homogenitas matriks varians-kovarians, dan uji kolinieritas variabel terikat. Berikut ini uraian mengenai hasil pengujian prasyaratnya.

Hasil pengujian normalitas sebaran data keyakinan diri dan prestasi belajar matematika siswa dengan uji KolmogorovSmirnov, diperoleh nilai signifikansi: keyakinan diri siswa pada kelompok eksperimen $=0,200$, kelompok kontrol $=$ 0,200 dan prestasi belajar matematika siswa pada kelompok eksperimen $=0,200$, kelompok kontrol $=0,091$. Dari hasil analisis tersebut diperoleh nilai signifikansi lebih dari 0,05 dengan demikian kedua kelompok sampel memiliki data yang berdistribusi normal.

Selanjutnya, hasil pengujian homogenitas varians data keyakinan diri dan prestasi belajar matematika siswa digunakan uji Levene. Berdasarkan hasil analisis diperoleh nilai signifikan keyakinan diri $=0,149$ dan prestasi belajar matematika siswa $=0,907$. Bila ditetapkan taraf signifikansi 0,05 maka untuk keyakinan diri maupun prestasi belajar matematika siswa tidak signifikan karena signifikansi keduanya lebih dari 0,05. Artinya baik keyakinan diri maupun prestasi belajar matematika siswa memliliki varians yang homogen.

Kemudian, hasil pengujian homogenitas matriks varians-kovarians data keyakinan diri dan prestasi belajar matematika siswa digunakan uji Box's $M$. Berdasarkan hasil analisis diperoleh nilai Box's $M=1,262$ dengan signifikansi = 0,752 jika ditetapkan taraf signifikansi 0,05 maka harga Box's M yang diperoleh tidak signifikan karena signifikansi yang diperoleh 0,499 >0,05. Dengan demikian matriks varians-kovarians dari variabel terikat sama.

Hasil uji kolinieritas keyakinan diri dan prestasi belajar matematika siswa kelompok eksperimen dengan menggunakan korelasi product moment pada taraf signifikansi 0,05 dengan bantuan SPSS 16.00 for windows menunjukkan bahwa untuk korelasi pearson sebesar 0,218 dengan taraf signifikansi 0,285 >0,05 dengan demikian antara keyakinan diri dan prestasi belajar matematika siswa pada kelompok eksperimen tidak berkolerasi. Hasil uji kolinieritas keyakinan diri dan prestasi belajar matematika siswa kelompok kontrol dengan menggunakan korelasi product moment pada taraf signifikansi 0,05 dengan bantuan SPSS 16.00 for windows menunjukkan bahwa untuk korelasi pearson sebesar 0,152 dengan taraf signifikansi $0,479>0,05$ dengaan demikian antara keyakinan diri dan prestasi belajar matematika siswa pada kelompok kontrol tidak berkolerasi 
Berdasarkan hasil pengujian prasyarat hipotesis dengan uji MANOVA.

tersebut maka dapat dilakukan pengujian

Tabel 3. Hasil Analisis Uji Manova

\begin{tabular}{llrrr}
\hline & & F & db hipotesis & \multicolumn{1}{c}{ Sig. } \\
\hline \multirow{2}{*}{ Kelas } & Pillai's Trace & $5,599^{a}$ & 2,000 & 0,007 \\
\cline { 2 - 5 } & Wilks' Lambda & $5,599^{a}$ & 2,000 & 0,007 \\
\cline { 2 - 5 } & Hotelling's Trace & $5,599^{a}$ & 2,000 & 0,007 \\
\cline { 2 - 5 } & Roy's Largest Root & $5,599^{a}$ & 2,000 & 0,007 \\
\hline
\end{tabular}

Hasil pengujian hipotesis pertama disajikan pada Tabel 3. Dimana diperoleh nilai-nilai statistik Pillai's Trace, Wilks'Lambda, Hotelling's Trace, dan Roy's Largest Root masing-masing $\mathrm{F}=5,599^{\mathrm{a}}$ dan memiliki signifikansi kurang dari 0,05 $(p<0,05)$. Hasil ini dijadikan dasar dalam mengambil keputusan. Adapun keputusan yang dapat diambil adalah $\boldsymbol{H}_{0}$ ditolak dan
$\boldsymbol{H}_{\mathbf{1}}$ diterima. Hasil ini menyatakan bahwa terdapat perbedaan keyakinan diri dan prestasi belajar matematika antara siswa yang mengikuti pembelajaran dengan asesmen formatif bentuk proyek dan siswa yang mengikuti pembelajaran dengan asesmen konvensional.

Tabel 4. Hasil Uji Lanjut

\begin{tabular}{|c|c|c|c|c|c|c|}
\hline Sumber & $\begin{array}{l}\text { Variabel } \\
\text { Terikat }\end{array}$ & JK & $\mathrm{db}$ & RJK & $\mathrm{F}$ & Sig. \\
\hline \multirow[t]{2}{*}{ Kelas } & $\begin{array}{l}\text { Keyakinan } \\
\text { Diri }\end{array}$ & 411,701 & 1 & 411,701 & 4,666 & 0,036 \\
\hline & Prestasi & 330,260 & 1 & 330,260 & 8,767 & 0,005 \\
\hline \multirow[t]{2}{*}{ Dalam } & $\begin{array}{l}\text { Keyakinan } \\
\text { Diri }\end{array}$ & 4235,679 & 48 & 88,243 & & \\
\hline & Prestasi & 1808,240 & 48 & 37,672 & & \\
\hline \multirow[t]{2}{*}{ Total } & $\begin{array}{l}\text { Keyakinan } \\
\text { Diri }\end{array}$ & 454189,000 & 50 & & & \\
\hline & Prestasi & 202483,000 & 50 & & & \\
\hline
\end{tabular}

Hasil pengujian hipotesis kedua disajikan pada Tabel 4. Didapatkan koefisien $F$ sebesar 4,666 dan memiliki signifikansi 0,036 kurang dari $0,05(p<0,05)$, sehingga nilai $F$ signifikan. Adapun keputusan yang dapat diambil adalah $\boldsymbol{H}_{\mathbf{0}}$ ditolak dan $\boldsymbol{H}_{\mathbf{i}}$ diterima. Terdapat perbedaan keyakinan diri antara siswa yang mengikuti pembelajaran dengan asesmen formatif bentuk proyek dan siswa yang mengikuti pembelajaran dengan asesmen konvensional.

Hasil pengujian hipotesis ketiga disajikan pada Tabel 4. Didapatkan koefisien $F$ sebesar 8,767 dan memiliki signifikansi 0,005 kurang dari 0,05 $(p<0,05)$, sehingga nilai $F$ signifikan. Adapun keputusan yang dapat diambil adalah $\boldsymbol{H}_{0}$ ditolak dan $\boldsymbol{H}_{\mathbf{1}}$ diterima. Terdapat perbedaan prestasi belajar matematika antara siswa yang mengikuti pembelajaran dengan asesmen formatif bentuk proyek 
dan siswa yang mengikuti pembelajaran dengan asesmen konvensional.

Berdasarkan uraian tentang hasil uji hipotesis di atas, dapat disajikan pembahasan sebagai berikut. Dari hasil pengujian hipotesis dapat disimpulkan bahwa pemberian asesmen formatif bentuk proyek berpengaruh terhadap keyakinan diri dan prestasi belajar matematika siswa.

Pembelajaran matematika dengan asesmen formatif bentuk proyek mampu mengajak siswa dalam investigasi dan berdiskusi secara intelektual, itu akan membuat siswa termotivasi dalam belajar, menemukan informasi, meningkatkan semangat ingin tahu, dan meningkatkan kemampuan bertanya. Dalam pembelajaran matematika yang berkaitan dengan keyakinan diri dan prestasi belajar matematika sangat tepat jika guru memilih asesmen formatif bentuk proyek untuk konsep tertentu guru perlu memberikan kesempatan kepada siswa untuk menemukan dan memilih sendiri jawaban atas rasa keingintahuan siswa terhadap permasalahan yang diberikan. Berbeda halnya dengan pembelajaran dengan asesmen konvensional dimana lebih mementingkan hasil daripada proses yang dilakukan siswa. Pembelajaran dengan asesmen konvensional akan mengurangi ruang gerak siswa untuk mengembangkan keyakinan diri dan prestasi belajarnyanya.

Pembelajaran matematika dengan asesmen formatif bentuk proyek diawali dengan pemberian LKS bentuk proyek kepada tiap kelompok. Pada LKS tersebut siswa diberikan masalah bentuk proyek, setelah mengamati permasalahan yang ada diproyek tersebut siswa berusaha mengeksplorasi berbagai data, informasi yang dibutuhkan dalam menyelesaikan masalah proyek di LKS dengan cara siswa dapat menjawab pertanyaan yang diberikan oleh guru maupun bertanya balik kepada guru. Kemudian siswa berusaha menemuka strategi/cara dalam penyelesaian masalah proyek yang diberikan pada LKS. Guru memfasilitasi siswa dalam menemukan strategi/cara penyelesaian masalah proyek yang diberikan pada LKS.

Jika siswa menemukan suatu masalah dalam pengerjaan proyek pada LKS, siswa dapat mengajukan pertanyaan terkait situasi atau masalah tertentu yang berkaitan dengan materi pembelajaran. Guru perlu memberikan kesempatan kepada siswa secara aktif untuk bertanya, sehingga guru dapat memprediksi siswa dalam memahami masalah dan mampu memecahkan masalah dengan baik. Kemudian, sesuai dengan arahan pada LKS, siswa mengidentifikasi strategi penyelesaian masalah yang dapat digunakan pada masalah lain. Siswa memikirkan apakah strategi tersebut dapat digunakan untuk menyelesaikan masalah lainnya. Dalam hal ini siswa menyelesaikan pengembangan masalah yang diberikan di LKS. Kegiatan ini membuat siswa terbiasa dalam membangun pengetahuan dan strategi mereka sendiri untuk menyelesaikan masalah. Guru memfasilitasi siswa untuk mengidentifikasi apakah strategi yang mereka gunakan berlaku untuk masalah lain yang lebih umum.

Kegiatan selanjutnya siswa menyelesaikan masalah matematika dengan menggunakan perencanaan yang telah dibuat. Kemudian salah satu kelompok siswa ditunjuk untuk mempresentasikan hasil diskusi kelompoknya, dan kelompok siswa lain memberikan komentar. Guru mengadakan klarifikasi dengan mengajukan pertanyaan efektif kepada siswa jika terdapat konsep yang keliru. Selanjutnya siswa mencermati dan merenungkan kembali keseluruhan proses pemecahan masalah yang sudah dilakukan secara utuh. Guru membimbing dan memfasilitasi siswa untuk mencermati kembali keseluruhan proses pemecahan masalah yang sudah dilakukan secara utuh. Keterlibatan siswa pada seluruh langkahlangkah dari asesmen formatif bentuk proyek menyebabkan proses pembelajaran berjalan dengan baik seiring peningkatan pemahaman siswa terhadap materi yang dipelajari, ini sejalan dengan Artha Pradnyana (2016) yang menyatakan bahwa pembelajaran dengan asesmen formatif bentuk proyek berpengaruh positif dibandingkan pembelajaran dengan asesmen konvensional.

Peran peneliti dalam hal ini adalah sebagai fasilitator dalam proses pembelajaran, berusaha menyediakan 
situasi yang kondusif untuk berlangsungnya proses pembelajaran, mendorong dan mengarahkan siswa untuk saling berinteraksi serta menuju konsep yang benar sehingga penyelesaian masalah yang diberikan menjadi lebih jelas. Peneliti juga menyajikan masalah-masalah yang menantang bagi siswa melalui pemberian LKS berupa proyek yang dikerjakan pada masing-masing kelompok sehingga muncul keinginan siswa untuk menemukan solusinya. Melalui pengerjaan LKS yang diberikan dapat mendorong siswa untuk berpikir kreatif dalam menemukan sendiri konsep matematika yang akan dipelajarinya sehingga kegiatan pemebelajaran yang dilaksanakan menjadi bermakna dan tentunya dapat menumbuhkan rasa senang siswa pada mata pelajaran matematika.

\section{KESIMPULAN DAN SARAN}

Kesimpulan yang diperoleh dari penelitian ini adalah sebagai berikut. (1) Terdapat perbedaan keyakinan diri dan prestasi belajar matematika antara siswa yang mengikuti pembelajaran dengan asesmen formatif bentuk proyek dan siswa yang mengikuti pembelajaran dengan asesmen konvensional. (2) Terdapat perbedaan keyakinan diri antara siswa yang mengikuti pembelajaran dengan asesmen formatif bentuk proyek dan siswa yang mengikuti pembelajaran dengan asesmen konvensional. (3) Terdapat perbedaan prestasi belajar matematika antara siswa yang mengikuti pembelajaran dengan asesmen formatif bentuk proyek dan siswa yang mengikuti pembelajaran dengan asesmen konvensional.

Berdasarkan kesimpulan di atas diajukan beberapa saran sebagai berikut. (1) Kepada praktisi pendidikan matematika, khususnya guru mata pelajaran matematika diharapkan untuk menerapkan asesmen formatif bentuk proyek sebagai salah satu alternatif asesmen dalam kegiatan pembelajaran di kelas mengingat memberikan pengaruh positif terhadap keyakinan diri dan prestasi belajar matematika siswa. (2) Penelitian ini dilakukan pada populasi dan materi pembelajaran yang terbatas. Para peneliti lain disarankan untuk melakukan penelitian terhadap asesmen ini dengan populasi yang lebih besar dan materi pembelajaran yang lebih luas untuk mengetahui pengaruh asesmen ini dalam pembelajaran matematika secara lebih mendalam. Peneliti lain juga disarankan agar mengujicobakan pengaruh asesmen formatif bentuk proyek ini pada aspek pembelajaran yang berbeda. (3) Penerapan asesmen formatif bentuk proyek dalam pembelajaran matematika diharapkan dapat menumbuhkan kesan yang selama ini dianggap sebagai mata pelajaran yang sulit untuk dimengerti oleh siswa kini menjadi senang dan tertarik untuk belajar matematika. Selain itu, dengan terjadinya interaksi antar siswa akan membuat pembelajaran lebih bermakna sehingga mampu meningkatkan keyakinan diri dan prestasi belajar matematika siswa.

\section{DAFTAR PUSTAKA}

Artha Pradnyana, Putu Ngurah. 2016. Pengaruh Asesmen Formatif Bentuk Proyek Terhadap Kreativitas dan Pemahaman Konsep Matematika Siswa Kelas VIII di SMP Laboratorium UNDIKSHA Singaraja. Skripsi. Singaraja: Universitas Pendidikan Ganesha

Bandura, Albert. 1997. Self Efficacy in Changing Society. USA: Stanford University

Candiasa, I Made, 2010a. Pengujian Instrumen Penelitian Disertai Aplikasi ITEMAN dan BIGSTEPS. Singaraja: Universitas Pendidikan Ganesha.

. I Made, 2010b. Statistik Univariat dan Bivariat Disertai Aplikasi SPSS. Singaraja: Universitas Pendidikan Ganesha.

I Made, 2010c. Statistik Multivariat Disertai Aplikasi SPSS. Singaraja: Universitas Pendidikan Ganesha.

Marhaeni. 2007. Asesmen Otentik dalam rangka KTSP suatu upaya pemberdayaan guru dan siswa. Makalah. Disampaikan pada 
Pelatihan KTSP bagi Guru SMP. Tanggal 10-14 September 2007 di Kabupaten Tabanan.

Mendiknas. 2006. Peraturan Mentri Pendidikan Nasional Republik Indonesia No. 22 Tahun 2006. Tersedia di https://asefts63.files.wordpress.com/ 2011/01/permendiknas-no-22-tahun2006-standar-isi.pdf (Diakses pada tanggal 12 januari 2016)

Nurjaman Hidayatullah. 2010. "Perbandingan prestasi belajar antara siswa dengan orang tua tunggal dan siswa dengan orang tua utuh". Terdapat pada isjd.pdii.lipi.go.id/index.php (diakses pada 20 Januari 2016)

Purnomo, Yoppy. W. 2013. Keefektifan Penilaian Formatif Terhadap Hasil Belajar Matematika Mahasiswa Ditinjau Dari Motivasi Belajar. (Makalah dipresentasikan dalam Seminar Nasional Matematika dan Pendidikan Matematika Universitas Negeri Yogyakarta.

S. Cahyo. 2010. "Faktor-faktor yang Mempengaruhi Prestasi Belajar Kewirausahaan Siswa Kelas XI SMK N 1 Punggelan Banjarnegara". Terdapat pada lib.unnes.ac.id/10709/1/6643.pdf (diakses pada 20 Januari 2016)

Slameto. 2003. Belajar dan Faktor-faktor yang Mempengaruhinya. Jakarta: PT Rineka Cipta.

Sugiyono. 2012. Metode Penelitian Pendidikan. Bandung: Alfabeta

Syaiful Bahri Djamarah. 1994. Prestasi Belajar dan Kompetensi Guru. Surabaya: Usaha Nasional 